\title{
Teacher Training and Competences for Effective CLIL Teaching in Argentina
}

\author{
Capacitación de profesores y competencias para la enseñanza \\ efectiva de CLIL en Argentina
}

\author{
María Inés Pistorio \\ Instituto Nuestra Sra. del Sagrado Corazón \\ (Córdoba, Argentina)
}

\begin{abstract}
Given the importance of Content Language Integrated Learning (CLIL) for bilingual institutions, Argentine universities and teaching training colleges need to incorporate this approach in their curricula to certify that graduate teachers are qualified to teach not only English as a foreign language (EFL) but also content-based subjects in English. This paper focuses on teacher training for the development of theoretical and methodological competences. While the former include knowledge of the theories that constitute the basis of content and language learning, the latter integrate teaching and learning strategies, as well as learning styles. Teacher training involving these competences results in effective CLIL teaching.
\end{abstract}

Key Words: teacher training; theoretical and methodological competences; teaching strategies; learning strategies; learning styles.

\section{Resumen}

Dada la importancia del aprendizaje integrado de contenido y lenguaje (CLIL) para instituciones bilingües, las universidades argentinas y los institutos de formación docente, necesitan incorporar ésta metodología a sus programas de estudio, a fin de certificar que los profesores egresados están calificados para enseñar no sólo inglés como lengua extranjera, sino también materias de contenido. Este trabajo enfatiza el entrenamiento docente tendiente a lograr el desarrollo de competencias teóricas y metodológicas. Las primeras incluyen conocimiento de las teorías que constituyen la base del aprendizaje (contenido y lenguaje). Las competencias metodológicas incluyen estrategias utilizadas por docentes y alumnos, así como también estilos de aprendizaje. El entrenamiento de los profesores que incluya estas competencias, resultará en una enseñanza efectiva de CLIL.

Palabras Claves: entrenamiento para profesores; competencias teóricas y metodológicas; estrategias de enseñanza; estrategias de aprendizaje; estilos de aprendizaje.

\section{INTRODUCTION}

A great body of pedagogical and psycholinguistic research reports significant benefits derived from the implementation of CLIL (Muñoz, 2002), an educational approach in which language and communication skills are given primary importance. In addition to increasing the students' exposure to the foreign language, CLIL also contributes to the development of cognitive abilities (Marsh, 2000); in fact, in a bilingual context, learners process concepts at a deep level and can better internalize and retain information.

Pistorio, María Inés. (2009). Teacher training and competences for effective CLIL teaching in Argentina. Latin American Journal of Content \& Language Integrated Learning, 2(2), 37-43. doi:10.5294/lacli1.2009.2.2.14 
Since CLIL is about using the language to learn and learning to use languages (Marsh, 2000), its emphasis is on language learning rather than on language teaching. However, the present study focuses on CLIL teachers rather than on CLIL learners, because of the need to build a more thorough foundation for the professionals required in bilingual institutions in Argentina where English is used as the medium of instruction of content-based material.

Universities and teaching training colleges certify that teachers are well qualified to teach English as a foreign language (EFL); nevertheless, CLIL teachers often find that they have serious limitations when confronted with the teaching of content-based material. In order to improve the quality of bilingual education, language experts and curriculum designers should give more attention to CLIL-teacher training, as well as to the professional competences that teachers need to develop during pre-service and in-service education.

\section{CLIL teacher competences in Europe}

Pavesi et al.(2001) summarize the competences needed by CLIL teachers; these include:

- knowledge of L1 to understand learners' difficulties and a good command of the language used for instruction

- good knowledge of the content subjects

- production of lesson plans

- planning and organization of lessons according to cognitive demands

- gradual content and language progression.

Marsh's (2002) report lists the theoretical and methodological competences for a CLIL teacher who is not expected to have either native speaker or near-native speaker level of the target language. Theoretically, a CLIL teacher must understand the differences between language learning and language acquisition. Methodologically, a CLIL teacher should be able to deal with first/second language interference for building concepts in content subjects and to introduce activities that link language and subject aspects. Similarly to Pavesi et al. (2001), Marsh (2002) explains that in addition to using teaching strategies, teachers should promote the following goals:

- interaction for the understanding of meaning

- learners' use of communication strategies

- recognition of the importance of information and communication technology.

However, in contrast to Pavesi et al. (2001), Marsh (2002) also suggests relating the concepts of different subjects to improve the effectiveness of learning.

In Europe, researchers designed an observation tool that tested effective CLIL teaching performance (de Graaf et al., 2007), and provided significant recommendations for L2 pedagogy in CLIL. The researchers found that effective pedagogical approaches related to content-based teaching and task-based language teaching are beneficial to both, CLIL teachers and noncontent-based language teachers. The study (de Graaf et al., 2007: 620) reports five main indicators for effective teaching performance:

1. Exposure to input at a challenging level by carefully selecting authentic materials, which are adapted to learners, and by scaffolding the content and language through body language and visual aids. 
2. Meaning focused processing by encouraging learners to ask for new vocabulary, and to provide corrective feedback either explicitly or implicitly when meanings are wrongly identified.

3. Form-focused processing by using recasts or confirmation checks although it is not reported that teachers used explicit form-focused instruction by giving explanations about rules.

4. Output by means of interaction.

5. Use of compensation strategies.

\section{Teacher training in Argentina}

The lack of CLIL teacher-training programs in Argentina suggests that the majority of teachers working in bilingual institutions may be ill-equipped to do their jobs adequately. In agreement with Navés and Muñoz (1999), teachers are often competent in the foreign language, but have no specific training in content subjects. In fact, they typically lack the theoretical and methodological background to plan content lessons and to gather, adapt, or design teaching materials. This often leads them to conclude that they do not qualify for jobs at bilingual institutions. Their teaching competences are not completely developed and, as a result, they feel they are invading other teachers' fields. Therefore, university and tertiary education should run courses within the curriculum that include theoretical and methodological aspects of CLIL teaching.

CLIL focuses both on content and language learning, so its implementation requires approaches, methodologies, teaching and learning strategies quite different from those in traditional foreign language teaching repertoires (Coyle, 1999). Unfortunately, there is no developed theory on which methodologies for all learning environments can be based; therefore, it becomes necessary for such a CLIL training program to follow certain guiding principles that are essential for bilingualism and second language acquisition.

\section{CLIL TEACHER COMPETNECES IN AREGENTINA: PRE-SERVICE AND IN- SERVICE TEACHER TRAINING}

\section{Language-based competences}

CLIL teachers in Argentina should have a good command of the English language and should resort to L1 with due care and consideration. Indeed, in the early stages of learning English, teachers can allow students to use code-switching because this is a natural communication strategy. Teachers must be flexible enough to adapt their instructional support in order to promote language learning, so their main concern should be to scaffold learners on their way towards becoming competent in both linguistic areas and in non-linguistic content subjects. Learners always need to have access to spontaneous speech in an interactive context (Pavesi et al., 2001; Marsh, 2002).

\section{Theoretical competences}

Newly qualified teachers should have a thorough knowledge of the theories and models that constitute the foundation of content and language learning. Taking into account the cognitive demands that content learning implies, Mohan (1986) proposes a model for the organization of

Pistorio, María Inés. (2009). Teacher training and competences for effective CLIL teaching in Argentina. Latin American Journal of Content \& Language Integrated Learning, 2(2), 37-43. doi:10.5294/lacli1.2009.2.2.14 
the curriculum based on a knowledge framework that is conducive to the development of communication, thinking and language. Mohan (1986) relates communication and thinking processes involving classification, principles, and evaluation, which are analyzed for their language demands. To develop content and language according to this model, teachers guide students in their transition from experiential learning (contextualized and concrete) to expository learning (de-contextualized and abstract). This model also puts long-term and short-term planning into practice, as well as requiring linguistic, content, and learning progression. It should be noted that Pavesi et al. (2001) address some of the teacher competences suggested in Mohan's (1986) model.

Teachers also need to become acquainted with the significance of incorporating cognitively demanding tasks (Coyle, 1999), and with Cummins and Swain's model (1986) which plots context-embedded and context-reduced tasks against those that require either high or low cognitive demands. Moreover, teachers need to know about Skehan's (1999) findings regarding three aspects of learner performance: fluency, accuracy and complexity. Skehan believes that tasks contribute to fostering the development of these three aspects of performance; however, it becomes impossible for a single task to accomplish the three goals owing to the limitations of the human information processing system. Consequently, learners have to compromise between the three dimensions of the task (fluency, accuracy, and complexity). Empirical evidence shown in Skehan (1999) suggests that complexity comes only at the cost of decreased fluency and accuracy. If students concentrate on the meanings they want to convey, they can attain fluency in speaking although they are bound to make mistakes in grammar, pronunciation, or vocabulary. On the other hand, if they concentrate on getting their grammar, pronunciation, and vocabulary right, their fluency decreases. If learners are provided with fluency tasks, their accuracy in speaking and writing develops relatively slowly. Conversely, if learners concentrate on accuracy exercises, their fluency will probably fail to develop satisfactorily. Skehan (1999) points out that fluency, accuracy, and complexity must be carefully considered when designing and sequencing tasks.

De Graaf et al. (2007) report that teachers do not use explicit form-focused processing by giving rule explanations; however, the knowledge of FonF (Focus on Form) techniques is an important theoretical competence that is included in this training program. Doughty and Williams (1998) take into account the significant differences between explicit and implicit knowledge and present two pedagogical approaches. On one hand, they propose both explicit teaching directing learners' attention towards the target forms, and speaking overtly about those forms. On the other hand, they propose implicit focus on form in order "to attract learner's attention and to avoid metalinguistic discussion, always minimizing any interruption to the communication of meaning" (Doughty and Williams, 1998, p. 232). It is important to note that all types of FonF instruction (explicit or implicit) should be adjusted according to age, language proficiency, and the characteristics of linguistic features.

\section{Methodological competences}

The methodological competences proposed for this program include teaching and learning strategies, learning styles, and instruction in different aspects of teaching and planning.

\section{Teaching strategies}

Pistorio, María Inés. (2009). Teacher training and competences for effective CLIL teaching in Argentina. Latin American Journal of Content \& Language Integrated Learning, 2(2), 37-43. doi:10.5294/laclil.2009.2.2.14 
The teaching strategies for this training program (Snow, 1998 cited in Coyle, 1999) were selected and adapted to facilitate adjustments in teaching styles. Other strategies were added as a result of class observation in bilingual schools. The selection includes:

- linking the abstract to the concrete

- support of compensation strategies

- exploiting world knowledge

- using realia and visuals

- comprehension checks

- Focus on Form (presentation of grammar point, phonic, lexis)

- paraphrasing, repeating, giving cues

- demonstrating, outlining

- scaffolding

- using an interactive approach

- promoting study skills

- encouraging vocabulary lists

- teaching language related skills

- giving instructions clearly

- describing tasks accurately

- sequencing tasks

- maintaining learners' engagement in tasks

- making input comprehensible and context embedded.

\section{Learning strategies}

O'Malley and Chamot (1994) devised the Cognitive Academic Language Learning Approach (CALLA), which is intended for use mainly in upper elementary secondary schools. This instructional model prepares ESL students for academic achievement, language development, and explicit instruction in learning strategies (cognitive, metacognitive, and social/affective). CLIL teachers should train students in the use of these strategies, which are very important because they constitute the building blocks that support the cognitive processes leading to learning. Strategies can help students improve their communicative competence, develop the target language for learning content subjects, and become independent learners. CALLA is effective not only in teaching science, where teachers can use hands-on learning activities that provide contextual support, but also in teaching mathematics, which has a more restricted language register than science. The key to successfully implementing a similar approach in a CLIL environment depends on extensive teacher training and professional development as well as on increasing expertise in learning strategies instruction.

\section{Learning styles}

Schools find it difficult to adapt to different learning styles for teaching language and contentbased subjects; therefore, they adopt a unique profile that must suit classes with more than thirty students (Marsh, 2000). When teachers know their students' learning styles, they use appropriate approaches, which result in equity and success for more learners. Applying assessment instruments like Kinsella's (1995) Perceptual Learning Strengths Survey and Classroom Work Style Survey, educators can better appreciate how students understand, organize, and retain 
experiences. CLIL training programs should contribute to raising teachers' awareness of the significance of implementing learning styles preferences in the classroom so as not to stigmatize learners but rather to empower them in a variety of contexts and tasks.

\section{CLIL teacher training in teaching and planning}

In addition to language, theoretical and methodological competences, CLIL teachers must be instructed in the following aspects:

- development of the knowledge, vocabulary and skills in teaching mathematics, science, social studies and other content subjects, which are part of the curriculum in bilingual schools,

- lesson observation in bilingual institutions to master subject specific skills, vocabulary and teacher-talk, and to elaborate observation sheets focused on these topics,

- plenary discussions based on participants' experience and observation sheets,

- planning content-subjects,

- working with a variety of textbooks and teaching materials suitable for CLIL (attention must be paid to the relation of the subject content and the background knowledge of the target language community),

- working with authentic and adapted material,

- using information technology,

- using interdisciplinarity to work cooperatively with L1 subject teachers,

- preparing micro-teaching of peers with feedback, which takes the form

- of analysis and discussion,

- teaching at a selected school,

- trainees' assessment by the school and tertiary or university teachers/supervisors.

\section{CONCLUSIONS}

CLIL is an educational approach with a strong impact on language learning. It has become a powerful tool and a motivating force to learn and offers a natural situation for learning language and content subjects. In some countries, teacher training for CLIL is already available; however, in Argentina, specialized teaching training courses need to be developed. This study proposes pre-service and in-service teacher training in order to develop the theoretical and methodological competences required for effective CLIL teaching.

\section{REFERENCES}

Coyle, D. (1999). Students in content and language integrated contexts: Planning for effective classrooms. In, J. Masih (Ed.), Learning through a foreign language: Models, methods and outcomes. London: Centre for Information on Language Teaching and Research (CILT).

Cummins, J. \& M. Swain (1986). Bilingualism in education: Theory, research, and policy. London: Longman.

Doughty C. \& Williams, J. (Eds.) (1998). Focus on form in second language acquisition. New York: Cambridge University Press.

Pistorio, María Inés. (2009). Teacher training and competences for effective CLIL teaching in Argentina. Latin American Journal of Content \& Language Integrated Learning, 2(2), 37-43. doi:10.5294/lacli1.2009.2.2.14 
de Graaf, R., Koopman, G., Anikina, Y. \& Westhoff, G. (2007). An observation tool for effective L2 pedagogy in content and language-integrated learning (CLIL). International Journal of Bilingual Education and Bilingualism, 10 (5), pp. 603-624.

Kinsella, K. (1995). Understanding and empowering diverse learners in the ESL classroom. In J.M. Reid, Learning styles in the ESL/EFL classroom. Boston: Heinle and Heinle.

O'Malley, J. M. and Chamot, A. U. (1994). The CALLA handbook: Implementing the cognitive academic language learning approach. U.S.A: Addison-Wesley Publishing Company.

Marsh, D. (2000). Using languages to learn and learning to use languages. (Eds.) D. Marsh \& G. Langé. Jyväskylä: University of Jyväskylä. Retrieved from http://www.clilcompendium.com/1uk.pdf.

Marsh, D. (2002). CLIL/ EMILE - The European dimension. Action, trends and foresight potential. Contract DG/EAC: European Commission. (Ed.) D. Marsh. Jyväskylä: University of Jyväskylä. Retrieved from http://www.phkarlsruhe.de/cms/fileadmin/user upload/dozenten/schlemminger/enseigne ment bilingue/Marsh-CLIL-EMILE.pdf.

Mohan, B. (1986). Language and content. Reading, MA: Addison Wesley.

Muñoz, C. (2002). Relevance and Potential of CLIL. In D.Marsh (Ed.), CLIL/ EMILE - The European dimension. Action, trends and foresight potential. Contract DG/EAC: European Commission. Jyväskylä: University of Jyväskylä. Retrieved from http://www.phkarlsruhe.de/cms/fileadmin/user_upload/dozenten/schlemminger/enseigne ment bilingue/Marsh-CLIL-EMILE.pdf.

Navés, T. \& Muñoz, C. (1999). CLIL experiences in Spain. In Marsh, D. \& Langé, G. (Eds.). Implementing content and language integrated learning. Jyväskylä: University of Jyväskylä.

Pavesi, M.,Bertocchi, D. , Hofmanová, M. \& Kasianka, M. (2001). Teaching through a foreign language: a guide for teachers and schools to using Foreign Language in Content Teaching, [32p.] In D. Langé (Ed.), Insegnare in una lingua straniera. Unterrichten durch eine Fremdsprache. Teaching through a foreign language. Enseñar en una lengua extranjera. Enseigner dans une langue vivante. Milan: M.I.U.R., Direzione Generale della Lombardia on behalf of TIE-CLIL. Retrieved from http://www.ub.es/filoan/CLIL/teachers.pdf.

Skehan, P. (1999). A cognitive approach to language learning. Oxford: Oxford University Press.

\section{BIODATA}

María Inés Pistorio obtained a Bachelor of Arts in English Language, National Technological University (UTN), Regional School Villa Maria, (Córdoba, Argentina). She is currently writing her dissertation as a candidate of the Magister in English on Applied Linguistics Degree, National University of Córdoba (UNC). She has served as an English Coordinator at private institutions in Córdoba, Argentina, and is an experienced teacher at elementary, secondary, tertiary and higher education levels. She is the Head Teacher of the courses Research Theory and Special Research Methodology which are part of the Bachelor of Arts in English Language, National Technological University, Regional School Venado Tuerto (Santa Fe, Argentina). Her area of research is in listening competence.

Pistorio, María Inés. (2009). Teacher training and competences for effective CLIL teaching in Argentina. Latin American Journal of Content \& Language Integrated Learning, 2(2), 37-43. doi:10.5294/laclil.2009.2.2.14 